\title{
The Comprehensive Identification of Roof Risk in a Fully Mechanized Working Face Using the Cloud Model
}

\author{
Yu Xiong ${ }^{1}$, Dezhong Kong ${ }^{1, *}$, Zhanbo Cheng ${ }^{2, *}$, Guiyi Wu ${ }^{1}$ and Qi Zhang ${ }^{1}$ \\ 1 College of Mining, Guizhou University, Guiyang 550025, China; gs.xiongy19@gzu.edu.cn (Y.X.); \\ gywu@gzu.edu.cn (G.W.); $201526070103 @$ chd.edu.cn (Q.Z.) \\ 2 School of Engineering, University of Warwick, Coventry CV4 7AL, UK \\ * Correspondence: dzkong@gzu.edu.cn (D.K.); Z.Cheng.4@warwick.ac.uk (Z.C.); Tel.: +86-18511072876 (D.K.); \\ $+44-07563935629$ (Z.C.)
}

check for

updates

Citation: Xiong, Y.; Kong, D.; Cheng, Z.; Wu, G.; Zhang, Q. The

Comprehensive Identification of Roof Risk in a Fully Mechanized Working Face Using the Cloud Model. Mathematics 2021, 9, 2072. https:// doi.org/10.3390/math9172072

Received: 14 July 2021

Accepted: 26 August 2021

Published: 27 August 2021

Publisher's Note: MDPI stays neutral with regard to jurisdictional claims in published maps and institutional affiliations.

Copyright: (c) 2021 by the authors. Licensee MDPI, Basel, Switzerland. This article is an open access article distributed under the terms and conditions of the Creative Commons Attribution (CC BY) license (https:/ / creativecommons.org/licenses/by/ $4.0 /)$.

\begin{abstract}
Roof accidents seriously affect the safe and efficient mining of the working faces. Therefore, it is necessary to assess and identify the possible and influencing factors on the occurrence of roof risk in a fully mechanized mining workface. In this study, based on the analytic hierarchy process and fuzzy comprehensive evaluation, a comprehensive standard cloud model was established through constructing a quantitative grade interval and calculating the weight of each index to achieve the aim of a roof risk assessment and identification. The accuracy of risk assessment was ensured by using the comprehensive analyses of various aspects, such as cloud digital features, risk assessment cloud image and standard cloud image. This showed that the main influencing factors on the occurrence of roof accidents were roof separation distance, weighting intensity and rib spalling followed by the coal body stress concentration, initial support force and geological conditions. Taking 42,115 fully mechanized working faces in the Yushen coal mining area as an engineering background, this model was adopted to assess and identify the risk of roof accidents through generating comprehensive assessment cloud images and introducing the Dice coefficient to calculate the similarity degree. The results showed that the overall risk of roof accidents in 42,115 working faces was regarded as grade II (general risk) through the overall index of comprehensive risk evaluation and a similarity degree of 0.8606 . The impact of roof condition was mainly influenced by the risk of roof accidents, while the support status, personal working status and coal body condition had a limited effect on the risk of roof accidents. The comprehensive standard cloud model proposed in this study had strong visibility and discovered the key parts of risk indexes easily to solve the problems of ambiguity and quantitative identification in traditional roof risk evaluation methods. Therefore, this model was worth promoting, because it laid the foundation for the intelligent identification and early warning system of roof accident risk in a fully mechanized mining workface.
\end{abstract}

Keywords: roof risk identification; analytic hierarchy process; cloud model; Dice coefficient; fully mechanized mining workface

\section{Introduction}

The main disasters from underground coal mining activities in China involve coal dust, gas, water, fire, and roof accidents. With the increase in mining intensity, various disasters in coal mines occur frequently. From January 2020 to July 2020, a total of 63 coal mine accidents occurred in China causing 88 deaths. Among them, the numbers of coal mine roof accidents and casualties were relatively high. The accidents were mainly caused by factors such as the instability of the surrounding rock structure of the working faces, the failure of supports, rib spalling, and the development of roof cracks [1-7], which resulted in roof collapse or end-face roof collapse. More serious is the fact that such roof accidents occurred in fully mechanized working faces, directly affecting the safety of mining activities, causing damage to machinery and equipment and even threatening the safety of several people [8-13]. Table 1 describes the specific conditions of five roof 
accidents which occurred in China in recent years. It can be shown that the occurrence of roof accidents mainly depended on support condition, the mechanical properties of the roof, the quality of the personnel, and the stability of the coal body. Obviously, the occurrences of roof accidents not only caused huge economic losses and more casualties, but they also had serious effects on the coal mining community. Therefore, it was necessary to strengthen the roof risk assessment and identify the fully mechanized mining workface to ensure the safety and productivity of coal mines.

Table 1. Specific conditions of five roof accidents in China.

\begin{tabular}{|c|c|c|c|}
\hline Date & Coal Mine & $\begin{array}{c}\text { Death } \\
\text { Toll }\end{array}$ & Reason Description \\
\hline 26 October 2019 & $\begin{array}{l}\text { 13,619 mining working } \\
\text { faces, Shiping No. } 1 \text { coal } \\
\text { mine, Sichuan Province }\end{array}$ & 6 & $\begin{array}{l}\text { Due to the influence of the geological } \\
\text { structure, stress superposition and } \\
\text { other factors, the hydraulic support } \\
\text { was compressed during fault crossing. } \\
\text { Thus, the broken rock above the } \\
\text { supports flowed into the working } \\
\text { faces from the front of the top beam } \\
\text { under the action of water. }\end{array}$ \\
\hline 4 May 2020 & $\begin{array}{l}301 \text { working faces, } \\
\text { Luoshanjing coal mine, } \\
\text { Guangxi Province }\end{array}$ & 2 & $\begin{array}{l}\text { The coal seam at the open-off cut of } \\
\text { the working faces was soft, and the } \\
\text { support strength of the wooden frame } \\
\text { was insufficient, which led to the } \\
\text { collapse of the coal seam and roof. }\end{array}$ \\
\hline 12 June 2020 & $\begin{array}{l}\text { 84,202 working faces, } \\
\text { Wuguantun coal mine, } \\
\text { Shanxi Province }\end{array}$ & 1 & $\begin{array}{l}\text { In the area of the supports } 57 \#-58 \# \\
\text { close to the coal face, operators did not } \\
\text { obey the relevant operator regulations, } \\
\text { and, over time, the move supports } \\
\text { resulted in the roof control distance } \\
\text { exceeding the requirements of the } \\
\text { operating regulations and further roof } \\
\text { collapse. }\end{array}$ \\
\hline 23 June 2020 & $\begin{array}{l}1221 \text { air-return roadway, } \\
\text { Ping'an coal mine, Hebei } \\
\text { Province }\end{array}$ & 1 & $\begin{array}{l}\text { Operators did not implement a } \\
\text { temporary support, and the lumber } \\
\text { was removed by hand causing coal } \\
\text { and rock to cave. }\end{array}$ \\
\hline 19 August 2020 & $\begin{array}{l}\text { 91,803 working faces, } \\
\text { Xingyun coal mine, } \\
\text { Yunnan Province }\end{array}$ & 1 & $\begin{array}{l}\text { The roof collapsed due to the influence } \\
\text { of geological structures (e.g., faults, a } \\
\text { broken roof and stress concentration), } \\
\text { and operators failed to reinforce the } \\
\text { supports in time. }\end{array}$ \\
\hline
\end{tabular}

In recent years, various methods have been adopted to analyze the factors causing roof accidents and to accurately assess roof risk. Normally, the neural network and neuro-fuzzy models have been widely adopted in the risk assessment of engineering [14-19]. Scholars have proposed relevant models to assess the risk probability and to use decision-making principles to manage risks based on the analysis of most coal mine roof accidents [20]. In order to avoid the structural problem of the method, the triangular fuzzy theory and the traditional fault tree could be combined to quantitatively analyze the reasons for roof collapse accidents [21]. Furthermore, the dynamic fuzzy evaluation method was used to construct the risk matrix to determine the mine roof risk level, which further effectively predicted the occurrence of risk possibility [22-24]. In addition, roof separation was an obvious precursor for the occurrence of roof accidents in a fully mechanized working face. Therefore, the gray theory analysis method was used to predict the roof separation distance. Combined with the gray algebraic curve model, the early warning system could be established to evaluate the occurrence of roof accidents [25]. The classification of roof 
grade was closely related to the geological conditions (e.g., faults) and roof strength (e.g., roof caving), which further affected the roof risk assessment [26]. In order to obtain the roof risk assessment of the soft rock roadway, the analytic hierarchy process and the entropy weight method were used to determine the comprehensive weight of each evaluation index. Combining MATLAB software, a risk assessment model was constructed to comprehensively evaluate its stability. It showed that the lithology was the main factor affecting roof stability [27]. Moreover, according to the US National Safety Commission, more than $80 \%$ of coal mine roof accidents were caused by human factors (e.g., personnel attention and irregular operation) [28,29]. Scholars also proposed a model based on the rock engineering system (RES) to assess the risk of roof collapse. Additionally, the tendency of roof collapse could be divided into four categories of safe, moderate, dangerous and critical regions, respectively [30]. All these results could effectively identify the damaged and safety areas of the roof to avoid the occurrence of roof accidents.

Throughout the literature review, although the methods mentioned above could qualitatively evaluate and predict roof risk, they were difficult to use to identify the main factors causing roof accidents. Additionally, the specific quantitative characteristics of each factor and the possibility of risk accidents could not be illustrated. In recent years, the cloud evaluation model with the characteristics of qualitative, quantitative and strong visibility has been successfully used in the assessment of the ecological environment of coal mines [31], gas drainage [32], mine ventilation [33], slope stability analysis [34,35] and other aspects [36-40]. Therefore, in this study, the analytic hierarchy process (AHP) was adopted to identify the causing factors of roof accidents and calculate the index weight of each factor. Additionally, a cloud model was then introduced to assess the possibility of the occurrence of roof accidents by using cloud images and the quantitative grade assessment method. Obviously, it provided theoretical guidance for identification, prevention and controlling of roof accidents to ensure the safe and efficient production of coal mines.

\section{Risk Evaluation Index System of Roof Accidents}

Through summarizing and analyzing the reasons of loads of roof accident cases, the causing factors of risk accidents could mainly be divided into four levels of support conditions (e.g., support distances, the touch degree of the supports and roof, initial support force, the efficiency of a single support), roof conditions (e.g., hanging roof areas before the first weighting, hanging roof areas after the first weighting, hanging roof area during the movement of working faces equipment, roof separation distances, geological conditions, weighting intensity) [41,42], personnel working status (e.g., illegally moving the supports, moving the support in time, dealing with the hanging roof in time, the integrity of a single support) $[43,44]$ and coal body status (e.g., rib spalling, soft coal seam and the stress concentration of coal body), including 17 indexes total. Table 2 describes the characteristics of each factor, and Figure 1 illustrates the comprehensive evaluation index system of the risk of roof accidents in a fully mechanized working face.

According to the risk evaluation index system (4 levels with 17 indexes total) of roof accidents, the risk grade could be divided into four categories of Grade I (low risk), Grade II (general risk), Grade III (larger risk) and Grade IV (major risk), which indicated the potential occurrence of roof accidents under the action of various causing factors. The standard of each risk grade corresponding to the value range of each index is illustrated in Table 3. 
Table 2. Description of each factor and the characteristics of the risk of roof accidents.

\begin{tabular}{|c|c|}
\hline Causing Factors & Risk Characterization \\
\hline Support distances & $\begin{array}{l}\text { If the hydraulic supports were overhauled, the support distances } \\
\text { were too large, and the gangue slipped from the supports }\end{array}$ \\
\hline $\begin{array}{l}\text { The touch degree of the } \\
\text { supports and roof }\end{array}$ & $\begin{array}{l}\text { If roof and hydraulic supports were not tightly connected, the } \\
\text { roof easily collapsed }\end{array}$ \\
\hline Initial support force & $\begin{array}{l}\text { If the initial support force was not up to the standard, the roof } \\
\text { easily collapsed }\end{array}$ \\
\hline $\begin{array}{l}\text { The efficiency of single } \\
\text { support }\end{array}$ & $\begin{array}{l}\text { If the pillar of hydraulic supports was not intact and could not be } \\
\text { effectively utilized, it easily caused roof collapse and hurt people }\end{array}$ \\
\hline $\begin{array}{l}\text { Hanging roof areas before } \\
\text { first weighting }\end{array}$ & $\begin{array}{l}\text { If the hanging areas of the main roof were too large before the } \\
\text { first weighting, the roof collapsed suddenly, and it caused the } \\
\text { occurrence of risk accidents }\end{array}$ \\
\hline $\begin{array}{l}\text { Hanging roof areas after first } \\
\text { weighting }\end{array}$ & $\begin{array}{l}\text { If the roof did not collapse in time after the first weighting, the } \\
\text { main roof could not collapse in time along with the large hanging } \\
\text { areas, causing the roof to collapse suddenly }\end{array}$ \\
\hline $\begin{array}{l}\text { Hanging roof areas during } \\
\text { the movement of working } \\
\text { faces equipment }\end{array}$ & $\begin{array}{l}\text { During the movement of working faces equipment, the hanging } \\
\text { roof areas were too large, causing the roof collapse easily }\end{array}$ \\
\hline Roof separation distances & The large of roof separation distances caused the roof collapse \\
\hline Geological conditions & $\begin{array}{l}\text { If the coal mining processes needed to pass through the special } \\
\text { geological structures, the roof was easily broken and collapsed to } \\
\text { cause the occurrence of roof accidents }\end{array}$ \\
\hline Weighting intensity & $\begin{array}{l}\text { If the weighting intensity of overlying strata was high, the roof } \\
\text { was easily broken and collapsed }\end{array}$ \\
\hline Illegally moving supports & If someone illegally moved the supports, people were easily hurt \\
\hline Moving supports in time & $\begin{array}{l}\text { If the supports were not moved in time to reach the minimum } \\
\text { control roof distances after coal cutting, it easily caused the } \\
\text { gangue to slip and the roof to collapse }\end{array}$ \\
\hline $\begin{array}{l}\text { Dealing with the hanging } \\
\text { roof in time }\end{array}$ & $\begin{array}{c}\text { If the hanging roof areas between the side of the working faces } \\
\text { and the side of the goaf exceeded the regulations, and the relevant } \\
\text { measures were not taken in time, the roof easily collapsed }\end{array}$ \\
\hline $\begin{array}{l}\text { The integrity of single } \\
\text { support }\end{array}$ & $\begin{array}{c}\text { If the conditions of the pillars and the upper roof were not } \\
\text { checked before the pillars were moved, the pillar caps could fall } \\
\text { off, and the high-pressure liquids of hydraulic supports were } \\
\text { ejected to cause the occurrence of roof collapse and people being } \\
\text { hurt }\end{array}$ \\
\hline Rib spalling & $\begin{array}{l}\text { Rib spalling caused the roof to collapse easily in the side of the } \\
\text { working faces }\end{array}$ \\
\hline Soft coal seam & $\begin{array}{l}\text { The soft coal seam caused the easy failure of coal body along with } \\
\text { the roof collapse }\end{array}$ \\
\hline $\begin{array}{l}\text { The stress concentration of } \\
\text { coal body }\end{array}$ & $\begin{array}{l}\text { The stress concentration in the coal body was prone to causing } \\
\text { the failure of the coal face and coal pillars and the roof collapse }\end{array}$ \\
\hline
\end{tabular}




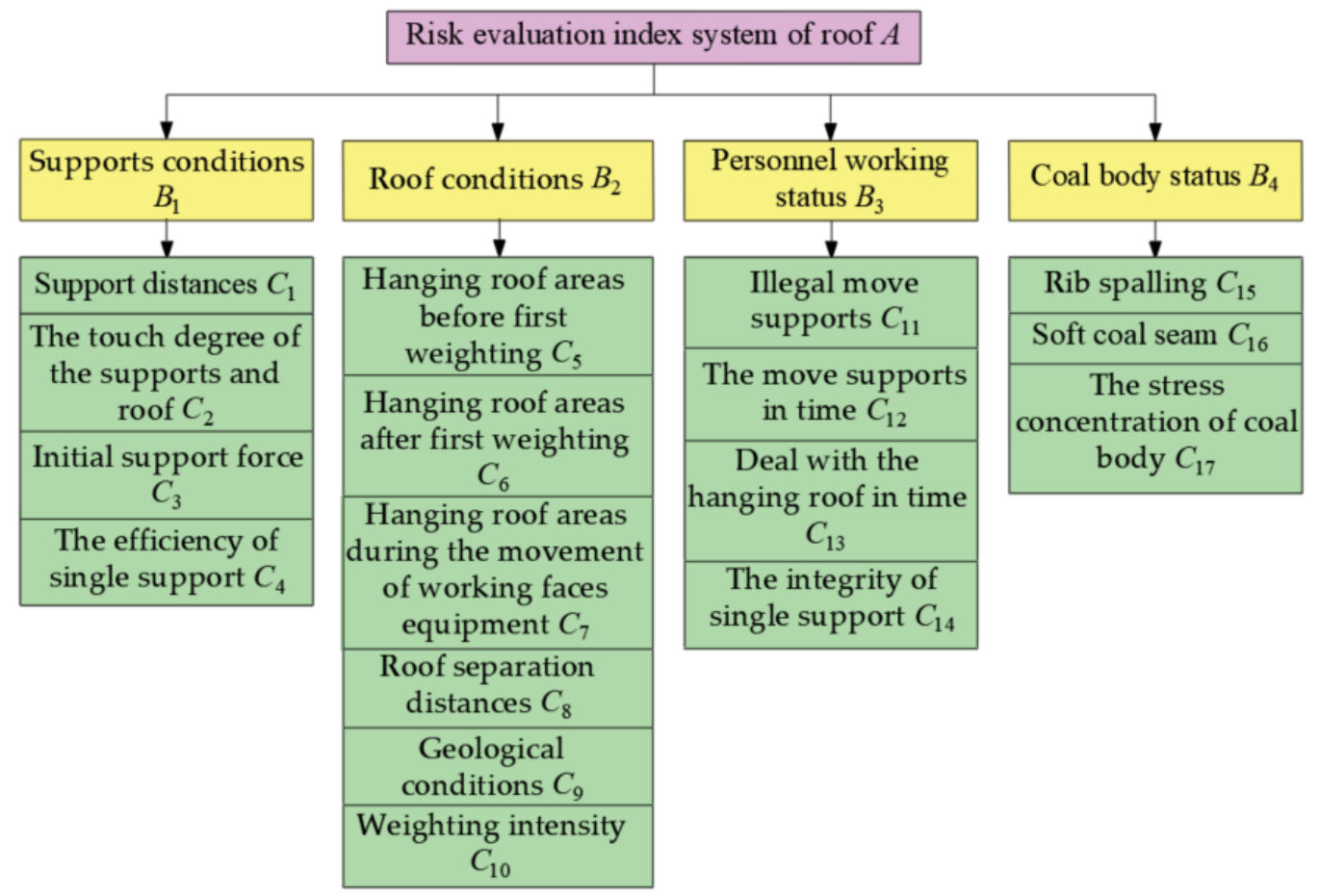

Figure 1. Risk evaluation index system of roof accidents in working faces.

Table 3. Risk evaluation grade standard of roof accidents.

\begin{tabular}{|c|c|c|c|c|}
\hline \multirow{2}{*}{ Risk Evaluation Indexes } & \multicolumn{4}{|c|}{ Evaluation Grade } \\
\hline & I & II & III & IV \\
\hline Support distances (mm) & $<200$ & $200 \sim 400$ & $400 \sim 600$ & $>600$ \\
\hline The touch degree of the supports and roof (\%) & $85 \sim 100$ & $70 \sim 85$ & $55 \sim 70$ & $<55$ \\
\hline Initial support force $(\%)$ & $85 \sim 100$ & $70 \sim 85$ & $55 \sim 70$ & $<55$ \\
\hline The efficiency of single support (\%) & $85 \sim 100$ & $70 \sim 85$ & $55 \sim 70$ & $<55$ \\
\hline Hanging roof areas before first weighting $\left(\mathrm{m}^{2}\right)$ & $<10$ & $10 \sim 20$ & $20 \sim 30$ & $>30$ \\
\hline Hanging roof areas after first weighting $\left(\mathrm{m}^{2}\right)$ & $<5$ & $5 \sim 10$ & $10 \sim 15$ & $>15$ \\
\hline $\begin{array}{l}\text { Hanging roof areas during the movement of working } \\
\text { faces equipment }\left(\mathrm{m}^{2}\right)\end{array}$ & $<10$ & $10 \sim 20$ & $20 \sim 30$ & $>30$ \\
\hline Roof separation distances $(\mathrm{cm})$ & $<20$ & $20 \sim 40$ & $40 \sim 60$ & $>60$ \\
\hline Geological conditions (Quantity) & $0 \sim 5$ & $5 \sim 10$ & $10 \sim 15$ & $>15$ \\
\hline Weighting intensity (0 100 level) & $<25$ & $25 \sim 50$ & $50 \sim 75$ & $>75$ \\
\hline Illegally moving supports (0 100 level) & $<25$ & $25 \sim 50$ & $50 \sim 75$ & $>75$ \\
\hline Moving supports in time (0 100 level) & $>75$ & $50 \sim 75$ & $25 \sim 50$ & $<25$ \\
\hline Dealing with the hanging roof in time $(0 \sim 100$ level $)$ & $>85$ & $55 \sim 85$ & $25 \sim 55$ & $<25$ \\
\hline The integrity of single support (0 100 level) & $>80$ & $50 \sim 80$ & $20 \sim 50$ & $<20$ \\
\hline Rib spalling $(\%)$ & $<15$ & $15 \sim 30$ & $30 \sim 45$ & $>45$ \\
\hline Soft coal seam (0 100 level) & $<25$ & $25 \sim 50$ & $50 \sim 75$ & $>75$ \\
\hline The stress concentration of coal body (0 100 level) & $<20$ & $20 \sim 45$ & $45 \sim 70$ & $>70$ \\
\hline
\end{tabular}

\section{Determining Each Risk Index Weight of Roof Accidents}

The analytic hierarchy process (AHP) was a qualitative and quantitative analysis and evaluation method, which decomposed the elements of the decision-making problem into three levels of objectives, criteria and programs [45-48]. The evaluation processes of using AHP mainly included the establishment of the hierarchical structure model, the construction of the judgment matrix groups and the calculation of each index weight. Moreover, consistency testing was conducted to verify the credibility of calculated weight results. Subsequently, the relevant elements were compared in pairs to assess the risk grade. In this study, according to comparison results, the importance grade from 1 to 9 was adopted to build two judgment matrices from program level to criterion level 
and from criterion level to objective level, respectively. Additionally, the weight vector was calculated through the maximum eigenvalue $\left(\lambda_{m}\right)$ of the judgment matrices. The corresponding eigenvector $U_{j}$ was expressed as follows:

$$
U_{j}=\left(U_{1}, U_{2}, U_{3}, \cdots, U_{n}\right)
$$

According to Equation (1), index weight $\left(\omega_{j}\right)$ and weight vector were calculated as follows:

$$
\begin{gathered}
\omega_{j}=\frac{U_{j}}{\sum_{j=1}^{n} U_{j}}(j=1,2, \cdots, n) \\
{\left[\omega_{1}, \omega_{2}, \cdots, \omega_{n}\right]^{\mathrm{T}}}
\end{gathered}
$$

In order to ensure the credibility of the weight results, a consistency test needs to be conducted based on the maximum eigenvalue $\left(\lambda_{m}\right)$ of judgment matrices. Additionally, the consistency index $(C I)$ and consistency ratio $(C R)$ were expressed as follows:

$$
\begin{gathered}
C I=-1+\frac{\lambda_{m}-1}{n-1} \\
C R=\frac{C I}{R I}
\end{gathered}
$$

where $R I$ was random index. And it was $0.58,0.9,1.12$ and 1.24 when the $n$ was $3,4,5$ and 6 , respectively [45].

If $C R$ was less than 0.1 , the test was regarded as pass $[49,50]$. Otherwise, the test failed. Additionally, the judgment matrices then needed to be further adjusted until the consistency test passed.

\subsection{Establishment of Judgment Matrices Groups and Calculation of Index Weight}

Based on the risk evaluation analysis of roof accidents and the hierarchy index system, the Delphi method was adopted to construct the judgment matrix of each index at the criteria level and program level. Moreover, through an expert scoring system and the loads of the relevant references, the values from 1 to 9 were assigned to represent the importance grade of each risk index of roof accidents in the working faces as shown in Table 4.

Table 4. Importance grade and its assignment value.

\begin{tabular}{cc}
\hline Importance Grade & Assignment \\
\hline Equally important & 1 \\
Slightly important & 3 \\
Obviously important & 5 \\
Strongly important & 7 \\
Extremely important & 9
\end{tabular}

Note: 2, 4, 6 and 8 represent the assignments whose importance was between the corresponding values of 1,3,5, 7 and 9 , respectively.

Firstly, the judgment matrix from criteria level to objectives level was shown as follows:

\begin{tabular}{ccccc}
\hline$A$ & $B_{1}$ & $B_{2}$ & $B_{3}$ & $B_{4}$ \\
\hline$B_{1}$ & 1 & $1 / 3$ & 2 & $1 / 2$ \\
$B_{2}$ & 3 & 1 & 4 & 2 \\
$B_{3}$ & $1 / 2$ & $1 / 4$ & 1 & $1 / 4$ \\
$B_{4}$ & 2 & $1 / 2$ & 4 & 1 \\
\hline
\end{tabular}

Obviously, the eigenvalue and eigenvector of this judgment matrix were calculated as 4.0458 and $(0.1564,0.46213,0.087717,0.29376)$, respectively. According to Equation (1), the vector of index weight $\left(\omega_{A}\left(B_{i}\right)\right)$ was expressed as follows:

$$
\omega_{A}\left(B_{i}\right)=[0.1564,0.4621,0.0877,0.2938]^{\mathrm{T}}
$$


Based on Equations (4) and (5), the consistency (CI) index and consistency ratio (CR) were 0.015273 and 0.01697 , respectively. Due to a $C R$ of less than 0.1 , the consistency test passed.

Secondly, the judgment matrices from the program level to each criterion level (support conditions $\left(B_{1}\right)$, roof conditions $\left(B_{2}\right)$, personnel working status $\left(B_{3}\right)$ and coal body status $\left.\left(B_{4}\right)\right)$ were shown as follows:

Support conditions $\left(B_{1}\right)$.

\begin{tabular}{|c|c|c|c|c|c|c|}
\hline$B_{1}$ & \multicolumn{2}{|r|}{$C_{1}$} & $C_{2}$ & \multicolumn{2}{|c|}{$C_{3}$} & $C_{4}$ \\
\hline$C_{1}$ & \multicolumn{2}{|r|}{1} & $1 / 4$ & \multicolumn{2}{|c|}{$1 / 5$} & $1 / 2$ \\
\hline$C_{2}$ & \multicolumn{2}{|r|}{4} & 1 & \multicolumn{2}{|c|}{$1 / 2$} & 3 \\
\hline$C_{3}$ & \multicolumn{2}{|r|}{5} & 2 & \multicolumn{2}{|c|}{1} & 4 \\
\hline$C_{4}$ & \multicolumn{2}{|r|}{2} & $1 / 3$ & \multicolumn{2}{|c|}{$1 / 4$} & 1 \\
\hline \multicolumn{7}{|c|}{ Roof conditions $\left(B_{2}\right)$. } \\
\hline$B_{2}$ & $C_{5}$ & $C_{6}$ & $C_{7}$ & $C_{8}$ & $C_{9}$ & $C_{10}$ \\
\hline$C_{5}$ & 1 & $1 / 2$ & 3 & $1 / 6$ & $1 / 4$ & $1 / 5$ \\
\hline$C_{6}$ & 2 & 1 & 3 & $1 / 5$ & $1 / 3$ & $1 / 4$ \\
\hline$C_{7}$ & $1 / 3$ & $1 / 3$ & 1 & $1 / 7$ & $1 / 5$ & $1 / 6$ \\
\hline$C_{8}$ & 6 & 5 & 7 & 1 & 3 & 2 \\
\hline $\mathrm{C}_{9}$ & 4 & 3 & 5 & $1 / 3$ & 1 & $1 / 3$ \\
\hline$C_{10}$ & 5 & 4 & 6 & $1 / 2$ & 3 & 1 \\
\hline
\end{tabular}

Personnel working status $\left(B_{3}\right)$.

\begin{tabular}{ccccc}
\hline$B_{3}$ & $C_{11}$ & $C_{12}$ & $C_{13}$ & $C_{14}$ \\
\hline$C_{11}$ & 1 & 4 & $1 / 2$ & 2 \\
$C_{12}$ & $1 / 4$ & 1 & $1 / 5$ & $1 / 3$ \\
$C_{13}$ & 2 & 5 & $1 / 4$ & 1 \\
$C_{14}$ & $1 / 2$ & 3 & & \\
\hline Coal body status $\left(B_{4}\right)$. & $C_{15}$ & $C_{16}$ & $C_{17}$ \\
\hline$B_{4}$ & 1 & 3 & $1 / 3$ \\
$C_{15}$ & $1 / 3$ & 1 & 1 \\
$C_{16}$ & $1 / 2$ & 3 & \\
$C_{17}$ & & 3 & \\
\hline
\end{tabular}

At the same time, based on Equations (1), (4) and (5), the vector of index weight, consistency index $(C I)$ and consistency ratio $(C R)$ of each criterion level and the corresponding results of the consistency test are also illustrated in Table 5. The eigenvalue and eigenvector of each judgment matrix are summarized in Table 6.

Table 5. Related calculation results of the judgment matrix.

\begin{tabular}{|c|c|c|c|c|c|c|}
\hline Criterion Level & $\begin{array}{c}\text { Eigenvalue of } \\
\text { Judgment Matrix }\end{array}$ & $\begin{array}{c}\text { Eigenvector of } \\
\text { Judgment Matrix }\end{array}$ & $\begin{array}{l}\text { Vector of Index } \\
\text { Weight }\end{array}$ & $\begin{array}{l}\text { Consistency } \\
\text { Index }(C I)\end{array}$ & $\begin{array}{l}\text { Consistency } \\
\text { Ratio }(C R)\end{array}$ & $\begin{array}{c}\text { Consistency } \\
\text { Test }\end{array}$ \\
\hline $\begin{array}{l}\text { Support conditions } \\
\qquad\left(B_{1}\right)\end{array}$ & 4.0484 & $\begin{array}{c}(0.077798,0.30557 \\
0.49184,0.12479)\end{array}$ & $\begin{array}{l}0.0778,0.3056 \\
0.4918,0.1248\end{array}$ & 0.017911 & 0.017911 & Pass \\
\hline Roof conditions $\left(B_{2}\right)$ & 6.282 & $\begin{array}{c}(0.057375,0.079261 \\
0.034083,0.38458 \\
0.16279,0.28191)\end{array}$ & $\begin{array}{l}0.0574,0.0792, \\
0.0341,0.3846, \\
0.1628,0.2819\end{array}$ & 0.056404 & 0.045487 & Pass \\
\hline $\begin{array}{c}\text { Personnel working } \\
\text { status }\left(B_{3}\right)\end{array}$ & 4.0728 & $\begin{array}{l}(0.2753,0.071639 \\
0.49783,0.15524)\end{array}$ & $\begin{array}{l}0.2753,0.0716 \\
0.4978,0.1553\end{array}$ & 0.024281 & 0.026979 & Pass \\
\hline Coal body status $\left(B_{4}\right)$ & 3.0536 & $\begin{array}{c}(0.52784,0.13965 \\
0.33252)\end{array}$ & $\begin{array}{c}0.5278,0.1397 \\
0.3325\end{array}$ & 0.026811 & 0.046225 & Pass \\
\hline
\end{tabular}


Table 6. Total ranking results of each risk index weight.

\begin{tabular}{cccccc}
\hline$C_{\boldsymbol{j}}$ & $\boldsymbol{B}_{\mathbf{1}}$ & $\boldsymbol{B}_{\mathbf{2}}$ & $\boldsymbol{B}_{\mathbf{3}}$ & $\boldsymbol{B}_{\mathbf{4}}$ & \\
\cline { 2 - 5 } & $\mathbf{0 . 1 5 6 4}$ & $\mathbf{0 . 4 6 2 1}$ & $\mathbf{0 . 0 8 7 7}$ & $\mathbf{0 . 2 9 3 8}$ & $\boldsymbol{\omega}_{\boldsymbol{A}}\left(\boldsymbol{C}_{\boldsymbol{j}}\right)$ \\
\hline$C_{1}$ & 0.0778 & 0 & 0 & 0 & 0.0122 \\
$C_{2}$ & 0.3056 & 0 & 0 & 0 & 0.0478 \\
$C_{3}$ & 0.4918 & 0 & 0 & 0 & 0.0769 \\
$C_{4}$ & 0.1248 & 0 & 0 & 0 & 0.0195 \\
$C_{5}$ & 0 & 0.0574 & 0 & 0 & 0.0265 \\
$C_{6}$ & 0 & 0.0792 & 0 & 0 & 0.0366 \\
$C_{7}$ & 0 & 0.0341 & 0 & 0 & 0.0158 \\
$C_{8}$ & 0 & 0.3846 & 0 & 0 & 0.1777 \\
$C_{9}$ & 0 & 0.1628 & 0 & 0 & 0.0752 \\
$C_{10}$ & 0 & 0.2819 & 0 & 0 & 0.1303 \\
$C_{11}$ & 0 & 0 & 0.2753 & 0 & 0.0241 \\
$C_{12}$ & 0 & 0 & 0.0716 & 0 & 0.0063 \\
$C_{13}$ & 0 & 0 & 0.4978 & 0 & 0.0437 \\
$C_{14}$ & 0 & 0 & 0.1553 & 0 & 0.0136 \\
$C_{15}$ & 0 & 0 & 0 & 0.5278 & 0.1551 \\
$C_{16}$ & 0 & 0 & 0 & 0.1397 & 0.0411 \\
$C_{17}$ & 0 & 0 & 0 & 0.3325 & 0.0977 \\
\hline
\end{tabular}

\subsection{Calculation of Total Weight of Each Risk Index}

Assuming that $\omega_{A}\left(C_{\mathrm{j}}\right)$ was the weight vector of program level $(C)$ in objective level $(A)$, the index weight was regarded as 0 if the index had a limited effect in program level $(C)$. Based on Equation (6), the rank results of each risk index weight are shown in Table 6.

$$
\omega_{A}\left(C_{j}\right)=\sum_{i=1}^{m} \omega_{A}\left(B_{i}\right) \omega_{B_{i}}\left(C_{j}\right),(j=1,2, \cdots, m)
$$

Table 6 illustrates that the weight of three indexes $\left(C_{8}, C_{15}\right.$ and $\left.C_{10}\right)$ was larger than the others, followed by $C_{17}, C_{3}$ and $C_{9}$. This demonstrates that the most important factors causing roof accidents were roof separation distances, weighting intensity and rib spalling followed by the stress concentration of coal body, initial support force and geological conditions.

In view of the traditional coal mine roof risk assessment methods (e.g., fuzzy mathematics, AHP and other evaluation methods), although the factors causing accidents and their risk weights were obtained, it was difficult to intuitively express the specific importance level of risk factors and quantify the risk evaluation grade due to the ambiguity characteristics of these traditional methods. Therefore, the cloud theory was introduced to construct a comprehensive cloud model of roof risk assessment in the working faces and then combined with qualitative and quantitative measures to effectively identify the specific roof risk grade.

\section{Standard Cloud Model of Roof Risk Assessment}

\subsection{Cloud Model}

The cloud model can transform the uncertainty relationship between qualitative and quantitative values into an intuitive and universal model, which mainly reflects the characteristics of fuzziness and randomness [51,52]. Normally, the digital features of expected value $\left(E_{x}\right)$, entropy value $\left(E_{n}\right)$ and super entropy value $\left(H_{\mathcal{e}}\right)$ are adopted to 
describe the characteristics of the cloud model as shown in Figure 2. These parameters could be obtained based on Equation (7) if the range of qualitative indexes was given:

$$
\left.\begin{array}{c}
E_{x}=\frac{C_{\max }+C_{\min }}{2} \\
E_{n}=\frac{C_{\max }-C_{\min }}{6} \\
H_{e}=k
\end{array}\right\}
$$

where $k$ is the uncertainly cohesion degree of assessment indexes, which was assigned according to the ambiguity and randomness of each risk index. $C_{\max }$ and $C_{\min }$ are the maximum and minimum values of the level interval in the cloud model, respectively.

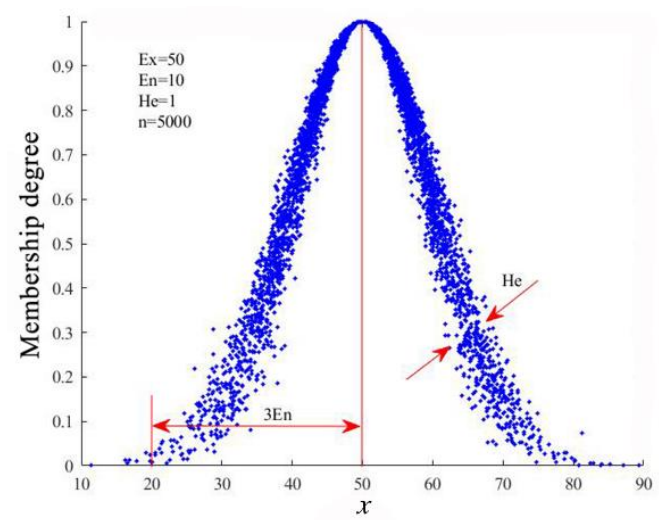

Figure 2. Feature picture of cloud model.

Based on the current evaluation method, the indexes were qualitatively expressed using the normal distribution of the comprehensive assessment system. Meanwhile, the risk evaluation framework of roof accidents in a fully mechanized working face based on cloud model theory is shown in Figure 3.

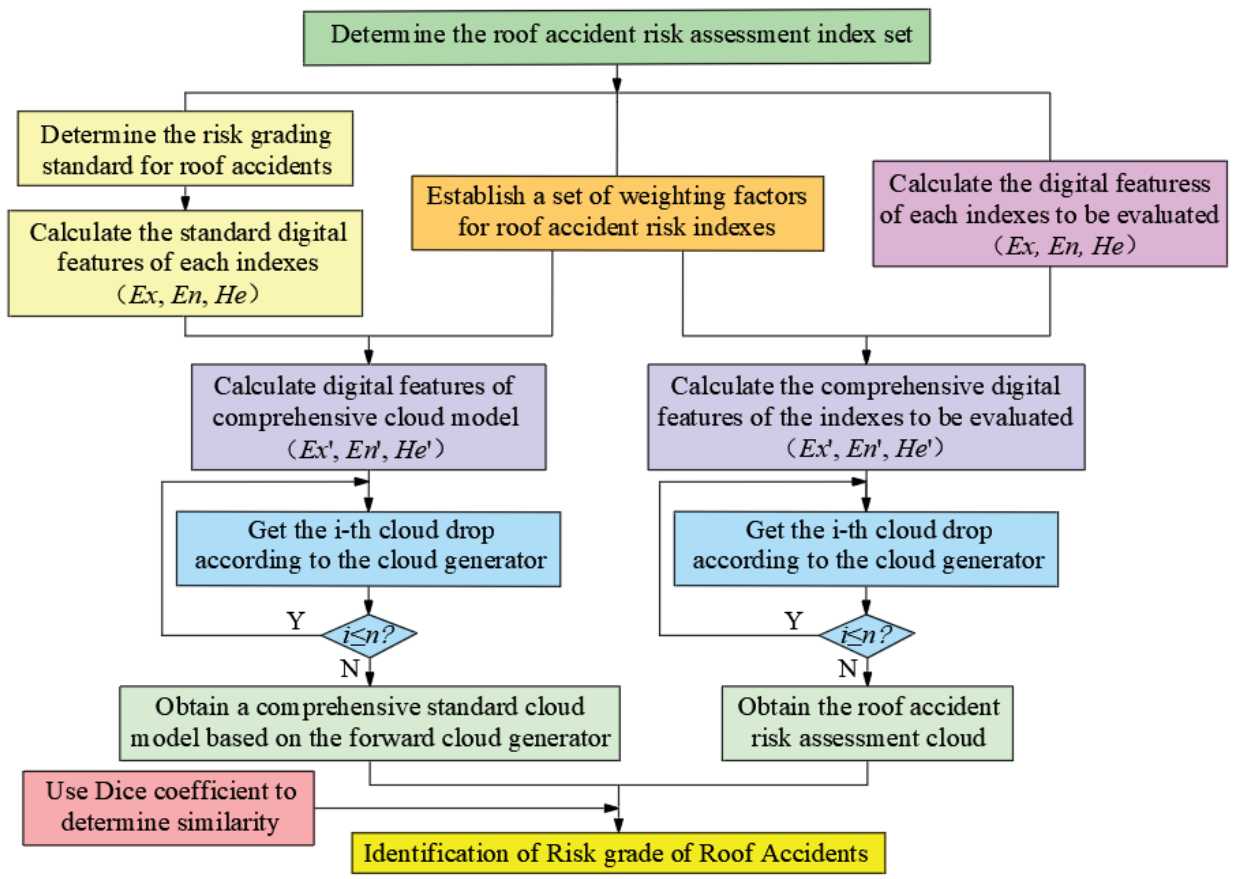

Figure 3. Risk evaluation framework of roof accidents in cloud model. 


\subsection{Establishment of Comprehensive Standard Cloud Model}

The grade interval of each index as shown in Table 3 was dimensionlessly processed to change it to the range of 0 to 1 by using the extreme value method. Based on Equation (7), the standard value features of all 17 causing factors and 4 evaluation grades were obtained, and then the weight of each index was also calculated through the analytic hierarchy process. Furthermore, according to Equation (8), the standard value features $\left(E_{x}, E_{n}\right.$ and $\left.H_{e}\right)$ of four indexes in the criterion level and the standard value features $\left(E_{x}, E_{n}\right.$ and $\left.H_{e}\right)$ of four risk assessment grades (e.g., I, II, III and IV) are listed in Tables 7 and 8, respectively:

$$
\left(E_{x}, E_{n}, H_{e}\right)=\left(\omega_{1} \omega_{2} \cdots \omega_{n}\right)\left(\begin{array}{ccc}
E_{x 1} & E_{n 1} & H_{e 1} \\
\vdots & \vdots & \vdots \\
E_{x n} & E_{n n} & H_{e n}
\end{array}\right)
$$

where $\omega_{n}$ is the weight of each index.

Table 7. Standard cloud digital features and evaluation grades in criterion level.

\begin{tabular}{ccccc}
\hline \multirow{2}{*}{$\begin{array}{c}\text { Indexes of } \\
\text { Criterion Level }\end{array}$} & I & Risk Evaluation Grade & II & III \\
\cline { 2 - 5 } & $(0,0.0526,0.05)$ & $(0.2367,0.0263,0.05)$ & $(0.3944,0.0263,0.05)$ & $(1,0.1755,0.05)$ \\
$B_{1}$ & $(0,0.0833,0.05)$ & $(0.375,0.0417,0.05)$ & $(0.625,0.0417,0.05)$ & $(1,0.0833,0.05)$ \\
$B_{2}$ & $(0,0.0641,0.05)$ & $(0.3338,0.0471,0.05)$ & $(0.6164,0.0471,0.05)$ & $(1,0.0807,0.05)$ \\
$B_{3}$ & $(0,0.0602,0.05)$ & $(0.2792,0.0329,0.05)$ & $(0.4764,0.0329,0.05)$ & $(1,0.1416,0.05)$ \\
$B_{4}$ & &
\end{tabular}

Table 8. Standard cloud digital features of four risk assessment grades.

\begin{tabular}{cc}
\hline Evaluation Grade & Digital Features \\
\hline I & $(0,0.07,0.05)$ \\
II & $(0.3216,0.0372,0.05)$ \\
III & $(0.5445,0.0372,0.05)$ \\
IV & $(1,0.1147,0.05)$ \\
\hline
\end{tabular}

The forward cloud generator of the MATLAB program was adopted to set 5000 cloud drops to generate the standard cloud model of four indexes in the criterion level and all causing factors as shown in Figures 4 and 5, respectively.

\subsection{Identification Criteria of Roof Risk Grade}

Normally, the roof risk grade of indexes could be obtained through the comparison of the cloud drops of the roof risk assessment cloud images with the corresponding roof risk grade interval of the standard cloud images. However, the roof risk grade of indexes could not be intuitively determined if the cloud drops of the roof risk assessment cloud images fell into two roof risk grade intervals of the standard cloud images at the same time. Under this condition, the Dice coefficient was further introduced to evaluate the roof risk grade by using the entropy value $\left(E_{n}\right)$ of the cloud images. According to Equation (9), the similarity degree between the roof risk assessment cloud images and the roof risk grade of the standard cloud images was obtained. Based on the maximum similarity principle, the corresponding roof risk assessment grade of the maximum Dice coefficient was regarded as the current roof risk grade in the working faces:

$$
\operatorname{Dice}(\mathrm{A}, \mathrm{B})=\frac{2|\mathrm{~A} \cap \mathrm{B}|}{|\mathrm{A}|+|\mathrm{B}|}
$$

where $|\mathrm{A}|$ and $|\mathrm{B}|$ are the interval length of a certain roof risk grade of the assessment cloud images and the standard cloud images, respectively, which were obtained through the entropy value $\left(E_{n}\right)$. $|\mathrm{A} \cap \mathrm{B}|$ is the intersection length of a certain risk grade between the roof risk assessment cloud images and the roof risk standard cloud images. 


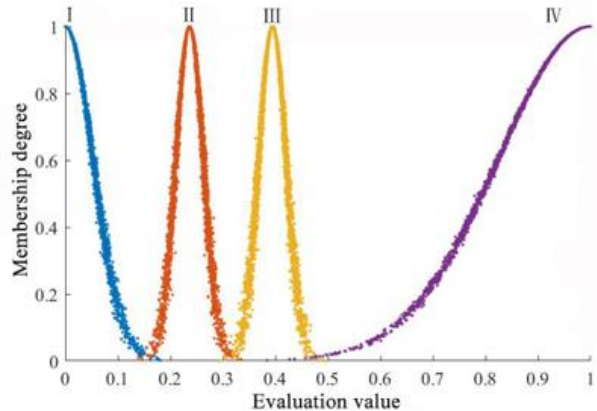

(a)

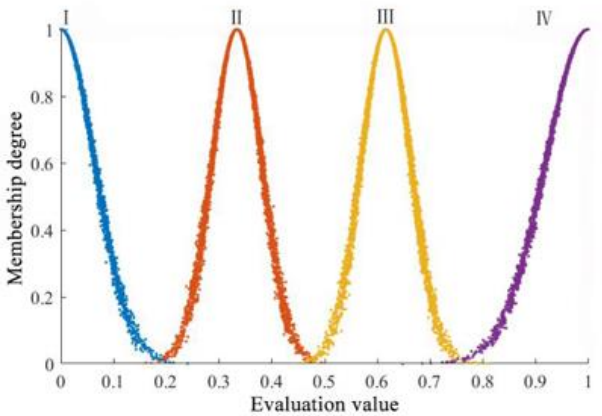

(c)

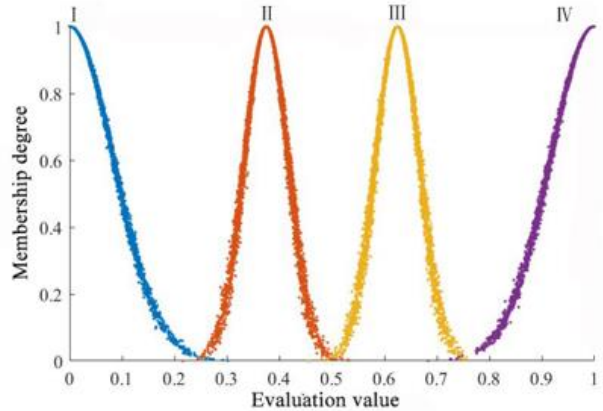

(b)

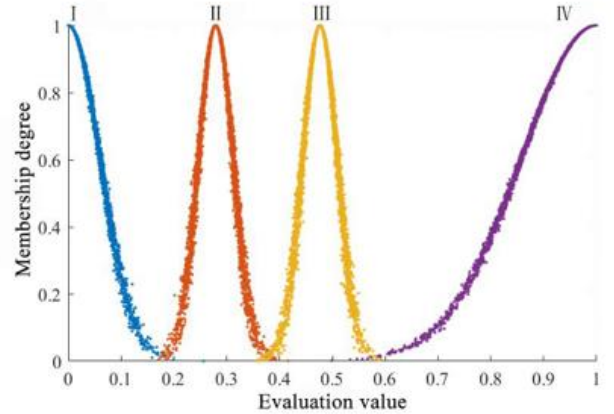

(d)

Figure 4. Comprehensive standard cloud model of four indexes in criterion level: (a) Support conditions; (b) Roof conditions; (c) Personnel working status; (d) Coal body status.

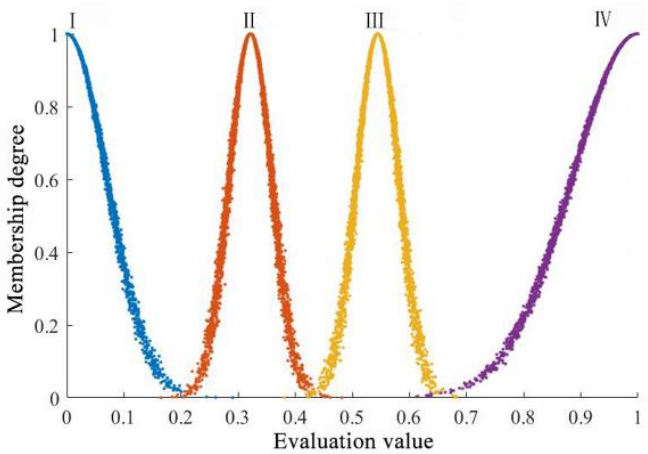

Figure 5. Comprehensive standard cloud model of all causing factors.

\section{Risk Identification of Roof Accidents-Case Study}

\subsection{Engineering Background}

Taking the 42,115 fully mechanized working faces in the Yushen mining area as the engineering background, the corresponding 4-2 coal seam of the working faces was relatively stable with an average thickness of $3.25 \mathrm{~m}$. Additionally, the immediate roof of the working faces was siltstone and fine sandstone with moderate stability (Grade II). Meanwhile, the main roof of the working faces was siltstone and fine-grained sandstone with dense, hard and good stability. In addition, it was investigated that there was no fault in the mining area based on the geological exploring conditions and the exposure conditions of the mining roadway in the working faces. Moreover, it was revealed that the beams were pressed, and eight existing points were eroded by sandstone. According to the on-site measurements, the first weighting caving distance of the immediate roof was about 13-16 m. Additionally, the first and periodic weighting caving distances of the main roof were about 35-40 $\mathrm{m}$ and $18 \mathrm{~m}$, respectively. The average moving distance between the roof and floor was about $0.1-0.25 \mathrm{~m}$. This illustrated that the obvious weighting intensity was 
observed. On the other hand, the rated initial support force and the maximum average support strength of hydraulic supports in the working faces were $8728 \mathrm{kN}$ and $994 \mathrm{kN} / \mathrm{m}^{2}$, respectively. The support was automatically moved according to the speed of the coal mining. The obtained actual overview conditions of all 17 risk evaluation indexes in the 42,115 fully mechanized working faces are shown in Table 9.

Table 9. Overview of all indexes of the 42,115 fully mechanized working faces.

\begin{tabular}{ccc}
\hline \multirow{2}{*}{ Risk Evaluation Indexes } & \multicolumn{2}{c}{ The 42,115 Fully Mechanized Working Faces } \\
\cline { 2 - 3 } & Maximum Value & Minimum Value \\
\hline$C_{1}$ & 100 & 5 \\
$C_{2}$ & 95 & 80 \\
$C_{3}$ & 95 & 80 \\
$C_{4}$ & 90 & 75 \\
$C_{5}$ & 40 & 30 \\
$C_{6}$ & 18 & 10 \\
$C_{7}$ & 25 & 15 \\
$C_{8}$ & 25 & 10 \\
$C_{9}$ & 15 & 8 \\
$C_{10}$ & 65 \\
$C_{11}$ & 15 & 5 \\
$C_{12}$ & 80 \\
$C_{13}$ & 95 & 85 \\
$C_{14}$ & 95 & 75 \\
$C_{15}$ & 85 & 5 \\
$C_{16}$ & 15 & 5 \\
$C_{17}$ & 10 & 25 \\
\hline
\end{tabular}

\subsection{Calculating the Digital Features of Each Roof Risk Index}

Firstly, each roof risk index was dimensionlessly processed, and the digital features of all indexes were obtained based on Equation (7) as shown in Table 10. According to Equation (8), combined with the index weight and digital features of each index, the comprehensive digital features of four indexes in the criterion level (e.g., support conditions, roof conditions, personnel working status and coal body status) are illustrated in Table 11. Furthermore, the digital features of all causing factors in the roof risk assessment cloud are expressed as follows:

$$
\left(\begin{array}{llll}
0.1564 & 0.4621 & 0.0877 & 0.2938
\end{array}\right)\left(\begin{array}{lll}
0.1266 & 0.0246 & 0.1086 \\
0.5049 & 0.0376 & 0.1290 \\
0.1173 & 0.0173 & 0.2330 \\
0.1713 & 0.0183 & 0.2042
\end{array}\right)=\left(\begin{array}{lll}
0.3137 & 0.0281 & 0.1570
\end{array}\right)
$$

\subsection{Generating Comprehensive Risk Evaluation Cloud Images}

According to the digital features of all risk evaluation indexes, 5000 cloud drops were set up in the standard cloud model to generate risk assessment cloud images as shown in Figures 6 and 7. Compared with the risk assessment cloud images and the standard cloud images, this directly showed that the cloud drops of the risk assessment cloud images were concentrated in the specific grade interval of standard cloud images. Meanwhile, based on the assessment cloud images and the entropy value $\left(E_{n}\right)$ of the standard cloud images, the Dice coefficient was calculated as shown in Table 12 to effectively identify the risk grade of roof accidents in the 42,115 fully mechanized working faces. 
Table 10. Cloud digital features of each risk evaluation index.

\begin{tabular}{|c|c|c|c|c|c|}
\hline \multirow{2}{*}{ Risk Evaluation Indexes } & \multicolumn{2}{|c|}{ Dimensionless Process } & \multirow{2}{*}{$E_{x}$} & \multirow{2}{*}{$E_{n}$} & \multirow{2}{*}{$\boldsymbol{H}_{\boldsymbol{e}}$} \\
\hline & Maximum Value & Minimum Value & & & \\
\hline$C_{1}$ & 0.125 & 0.00625 & 0.0656 & 0.0198 & 0.05 \\
\hline$C_{2}$ & 0.2 & 0.05 & 0.125 & 0.025 & 0.1 \\
\hline$C_{3}$ & 0.2 & 0.05 & 0.125 & 0.025 & 0.1 \\
\hline$C_{4}$ & 0.25 & 0.1 & 0.175 & 0.025 & 0.2 \\
\hline$C_{5}$ & 1 & 0.75 & 0.875 & 0.0416 & 0.1 \\
\hline $\mathrm{C}_{6}$ & 0.9 & 0.5 & 0.7 & 0.0667 & 0.1 \\
\hline$C_{7}$ & 0.625 & 0.375 & 0.5 & 0.0417 & 0.1 \\
\hline$C_{8}$ & 0.3125 & 0.125 & 0.219 & 0.0312 & 0.05 \\
\hline $\mathrm{C}_{9}$ & 0.75 & 0.4 & 0.575 & 0.0583 & 0.05 \\
\hline$C_{10}$ & 0.8 & 0.65 & 0.725 & 0.025 & 0.3 \\
\hline$C_{11}$ & 0.15 & 0.05 & 0.1 & 0.0167 & 0.32 \\
\hline$C_{12}$ & 0.2 & 0.05 & 0.125 & 0.025 & 0.2 \\
\hline$C_{13}$ & 0.15 & 0.05 & 0.1 & 0.0167 & 0.2 \\
\hline$C_{14}$ & 0.25 & 0.15 & 0.2 & 0.0167 & 0.2 \\
\hline$C_{15}$ & 0.15 & 0.05 & 0.1 & 0.0167 & 0.15 \\
\hline$C_{16}$ & 0.1 & 0.05 & 0.075 & 0.0083 & 0.3 \\
\hline$C_{17}$ & 0.4 & 0.25 & 0.325 & 0.025 & 0.25 \\
\hline
\end{tabular}

Table 11. Comprehensive digital features of four indexes in criterion level.

\begin{tabular}{cccc}
\hline First-Level Indexes & $\boldsymbol{E}_{\boldsymbol{x}}$ & $\boldsymbol{E}_{\boldsymbol{n}}$ & $\boldsymbol{H}_{\boldsymbol{e}}$ \\
\hline$B_{1}$ & 0.1266 & 0.0246 & 0.1086 \\
$B_{2}$ & 0.5049 & 0.0376 & 0.1290 \\
$B_{3}$ & 0.1173 & 0.0173 & 0.2330 \\
$B_{4}$ & 0.1713 & 0.0183 & 0.2042 \\
\hline
\end{tabular}

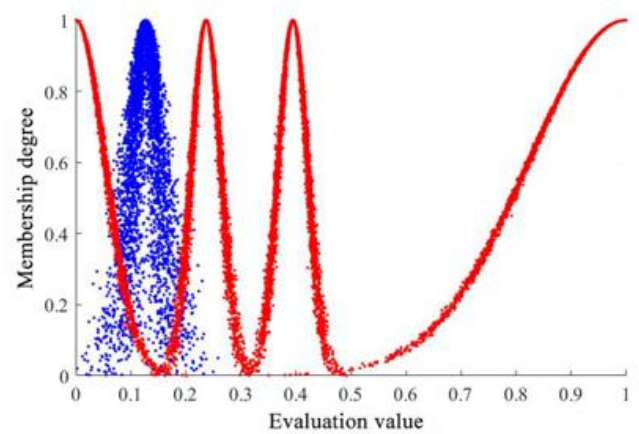

(a)

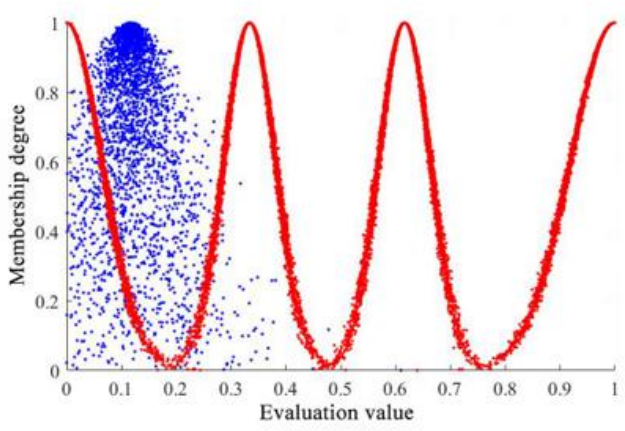

(c)

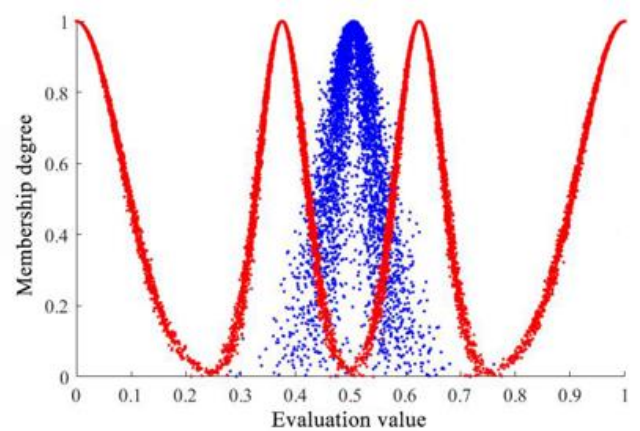

(b)

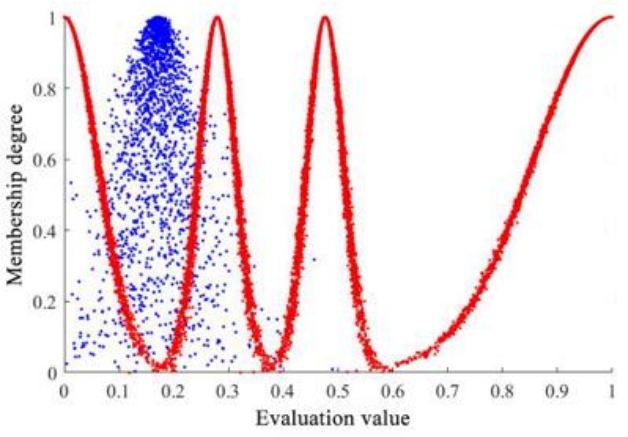

(d)

Figure 6. Cloud pictures of comprehensive risk evaluation indexes in criterion level: (a) Support conditions; (b) Roof conditions; (c) Personnel working status; (d) Coal body status. 


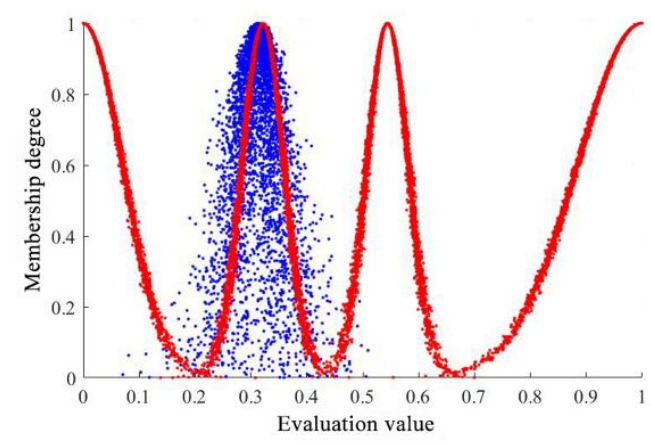

Figure 7. Cloud picture of comprehensive risk evaluation of all indexes.

Table 12. The similarity between the roof risk assessment cloud pictures and the standard cloud pictures.

\begin{tabular}{|c|c|c|c|c|c|}
\hline \multirow{2}{*}{ Comprehensive Evaluation Indexes } & \multirow{2}{*}{ The Range of Evaluation Cloud } & \multicolumn{4}{|c|}{ Evaluation Grade } \\
\hline & & I & II & III & IV \\
\hline$B_{1}$ & $(0.0528,0.2004)$ & 0.6876 & 0.2789 & 0 & 0 \\
\hline$B_{2}$ & $(0.3921,0.6177)$ & 0 & 0.4539 & 0.4943 & 0 \\
\hline$B_{3}$ & $(0.0654,0.1693)$ & 0.7011 & 0 & 0 & 0 \\
\hline$B_{4}$ & $(0.1164,0.2262)$ & 0.44 & 0.2971 & 0 & 0 \\
\hline All indexes & $(0.2294,0.398)$ & 0 & 0.8606 & 0 & 0 \\
\hline
\end{tabular}

As shown in Figure 6a, the risk assessment cloud image of support conditions intersected with Grade I and Grade II of the standard cloud model. However, the evaluation cloud drops were mainly concentrated in Grade I. On the other hand, through the calculation of the similarity degree, the evaluation was 0.6876 and 0.2789 for comparing the risk assessment cloud images with Grade I and Garde II of the standard cloud model, respectively. Therefore, the comprehensive risk grade of support conditions in the 42,115 fully mechanized working faces was regarded as Grade I (low risk).

Figure $6 \mathrm{~b}$ illustrates the risk assessment of roof conditions in the 42,115 fully mechanized working faces. It was observed that the risk assessment cloud image was intersected with Grade II and Grade III of the standard cloud model. Additionally, the entropy values $\left(E_{n}\right)$ of Grade II and Grade III of the standard cloud model were same. It was only seen that the cloud drops of risk assessment were a little bit denser within the range of Grade III. Moreover, through the calculation of the similarity degree, the evaluation was 0.4539 and 0.4943 for comparing the risk assessment cloud images with Grade II and Grade III of the standard cloud model, respectively. Based on the maximum similarity principle, the risk grade of roof conditions was regarded as Grade III (large risk) in the 42,115 fully mechanized working faces.

As shown in Figure 6c, the cloud drops of risk assessment of personnel working status basically fell into the range of Grade I of the standard cloud model. Through the calculation of the similarity degree, the evaluation was 0 for comparing the risk assessment cloud image with Grade II, Grade III and Grade IV of the standard cloud model. This fully revealed that the risk grade of personnel working status was Grade I (low risk) in the 42,115 fully mechanized working faces.

Figure $6 \mathrm{~d}$ shows that the risk assessment cloud image of coal body status was intersected with Grade I and Grade II of the standard cloud model. Additionally, the evaluation cloud drops were mainly concentrated in Grade I. Through the calculation of the similarity degree, the evaluation was 0.44 and 0.2971 for comparing the risk assessment cloud images with Grade I and Grade II of the standard cloud model, respectively. Therefore, the risk grade of coal body status was Grade I (low risk) in the 42,115 fully mechanized working faces.

In Figure 7, it is intuitively illustrated that the comprehensive risk assessment cloud drops of all 17 indexes basically fell into the range of Grade II of the standard cloud model 
in the 42,115 fully mechanized working faces. In addition, through comparing the risk evaluation assessment cloud image with the standard could model image, the similarity degree of Grade II was 0.8606, while the corresponding similarity degree of Grade I, Grade III and Grade IV was 0 . This explained that the risk grade of roof accidents in the 42,115 intelligent fully mechanized working faces was Grade II (general risk). In summary, support conditions, personnel working status and coal body status had limited effect on the occurrence of roof accidents, while the roof conditions in the working faces had a large risk in terms of the potential occurrence of roof accidents. Therefore, the management of roof conditions should be further strengthened in the whole mining processes of the 42,115 fully mechanized working faces.

\section{Conclusions}

A comprehensive risk evaluation cloud model of roof accidents was constructed based on the weight and standard grade level of each roof risk evaluation index. It effectively solved the problems of ambiguity and difficulty in quantitative expression and lacking visible results in the traditional risk evaluation methods of roof accidents. In terms of one specific engineering condition, the evaluation cloud images could be generated based on the newly proposed model, and then the Dice coefficient could be used to calculate the similarity degree between the risk evaluation cloud images and the risk grade interval of the standard cloud model. The qualitative and quantitative roof risk grade of the working faces could be effectively identified. Moreover, this model could also be widely used in the risk assessment process of various other potential accidents in coal mines. It provides theoretical guidance for effectively identifying, preventing and controlling the various accidents in coal mines and for ensuring the safe and efficient production of coal mines. Some conclusions are illustrated as follows.

(1) A comprehensive risk assessment model of roof accidents, including 4 indexes in the criterion level and a total of 17 causing factors, was constructed in a quantitative identification roof risk grade. Additionally, the main causing factors of roof accidents were roof separation distances, weighting intensity and rib spalling followed by the stress concentration of coal body, initial support force and geological conditions through the values of index weight determined by using the analytic hierarchy process.

(2) Based on the comprehensive risk assessment cloud images, the overall risk grade in 42,115 intelligent fully mechanized working faces was regarded as Grade II (general risk). Additionally, the support conditions, personnel working status and coal body status had limited effect on the occurrence of roof accidents, while there was a large risk (Grade III) for roof conditions in the potential occurrence of roof accidents.

(3) Compared with the AHP evaluation results, we showed that the risk assessment cloud model proposed in this study could identify the risk grade of each index and output comprehensive results by considering various aspects, such as cloud digital features, risk assessment cloud images and standard cloud images. It was effective in solving the problems of the ambiguity and difficulty of quantitative identification of traditional risk assessment methods, and it is worth promoting.

Author Contributions: Y.X.: Data curation, Formal analysis, Investigation, Software, WritingOriginal draft; D.K.: Conceptualization, Data curation, Funding acquisition, Methodology, Project administration, Writing-Review and editing; Z.C.: Formal analysis, Methodology, Validation, Writing-Review and editing; G.W.: Funding acquisition, Project administration, Resources, Supervision, Validation, Visualization; Q.Z.: Formal analysis, Investigation. All authors have read and agreed to the published version of the manuscript.

Funding: This research was funded by the National Natural Science Foundation of China Youth Fund (No. 51904082), the National Natural Science Foundation of China Regional fund (No. 52064005, 52164005, 52164002), funding from Guizhou Science and Technology Plan Project (Qianke Science Foundation [2020] 1y214), funding from Guizhou Science and Technology Plan Project (Qianke Science Support [2021] General 399), the Beijing Natural Science Foundation (Grant No. 2204080), 
the National Natural Science Foundation of China (Grant No. 52004010), the Opening Project Fund of Key Laboratory of Mining Disaster Prevention and Control (MDPC202019), the Scientific and Technological Innovation Talents Team in Guizhou Province (Project No. [2019] 5619), and China Scholarship Council (No. 201706430044).

Institutional Review Board Statement: Not applicable.

Informed Consent Statement: Not applicable.

Data Availability Statement: All data used during the study appear in the submitted article.

Conflicts of Interest: The authors declare no conflict of interest.

\section{References}

1. Cheng, J.; Wan, Z.; Ji, Y.; Zhang, R.R. Shield-Roof Interaction in Longwall Panels: Insights from Field Data and Their Application to Ground Control. Adv. Civ. Eng. 2018, 2018, 3031714. [CrossRef]

2. Kong, D.; Xiong, Y.; Cheng, Z.; Wang, N.; Wu, G.; Liu, Y. Stability analysis of coal face based on coal face-support-roof system in steeply inclined coal seam. Geomech. Eng. 2021, 25, 233-243.

3. Liu, Y.; Wang, X. Accident Analysis and Prevention Measure of Dynamic Load Mine Pressure of the 31201 Fully Mechanized Working Face of Shigetai Coal Mine. In Proceedings of the 2015 International Conference on Energy, Materials and Manufacturing Engineering (EMME 2015), Kuala Lumpur, Malaysia, 15-16 October 2015; Volume 25, p. 03001. [CrossRef]

4. Cheng, Z.; Li, L.; Zhang, Y. Laboratory investigation of the mechanical properties of coal-rock combined body. Bull. Eng. Geol. Environ. 2020, 79, 1947-1958. [CrossRef]

5. Cheng, Z.; Yang, S.; Li, L.; Zhang, L. Support working resistance determined on top-coal caving face based on coal-rock combined body. Geomech. Eng. 2019, 19, 255-268. [CrossRef]

6. Lv, H.; Tang, Y.; Zhang, L.; Cheng, Z.; Zhang, Y. Analysis for mechanical characteristics and failure models of coal specimens with non-penetrating single crack. Geomech. Eng. 2019, 17, 355-365. [CrossRef]

7. Cheng, Z.; Pan, W.; Li, X.; Sun, W. Numerical simulation on strata behaviours of TCCWF influenced by coal-rock combined body. Geomech. Eng. 2019, 19, 269-282. [CrossRef]

8. Yasidu, U.M.; Fujii, Y.; Kodama, J.; Fukuda, D.; Maneya, G.J.; Dandadzi, J.; Dassanayake, A.B.N.; Zhang, R.R. Influences of Water Vapor on Roof Fall Accidents in Selected Underground Coal Mines in Malawi. Adv. Civ. Eng. 2019, 2019, 5350686. [CrossRef]

9. Xiong, Y.; Kong, D.; Wu, G.; Li, Q. Study on the Support Capacity Determination and Movement Law of Overlying Strata in a Thin-Bedrock Large-Cutting-Height Longwall Panel. Geotech. Geol. Eng. 2021, 39, 2347-2358. [CrossRef]

10. Lou, J.; Gao, F.; Yang, J.; Ren, Y.; Li, J.; Wang, X.; Yang, L. Characteristics of evolution of mining-induced stress field in the longwall panel: Insights from physical modeling. Int. J. Coal Sci. Technol. 2021, 24. [CrossRef]

11. Kong, D.; Cheng, Z.; Zheng, S. Study on the failure mechanism and stability control measures in a large-cutting-height coal mining face with a deep-buried seam. Bull. Eng. Geol. Environ. 2019, 78, 6143-6157. [CrossRef]

12. Lv, H.; Cheng, Z.; Liu, F. Study on the mechanism of a new fully mechanical mining method for extremely thick coal seam. Int. J. Rock Mech. Min. Sci. 2021, 142, 104788. [CrossRef]

13. Kong, D.; Pu, S.; Cheng, Z.; Wu, G.; Liu, Y. Coordinated Deformation Mechanism of the Top Coal and Filling Body of Gob-Side Entry Retaining in a Fully Mechanized Caving Face. Int. J. Geomech. 2021, 21, 04021030. [CrossRef]

14. Hassani, M.; Behnam, B.; Maknoon, R. A risk-based framework for design of concrete structures against earthquake. Comput. Concr. 2020, 25, 167-179. [CrossRef]

15. Li, W.; Ye, Y.; Wang, Q.; Wang, X.; Hu, N. Fuzzy risk prediction of roof fall and rib spalling: Based on FFTA-DFCE and risk matrix methods. Environ. Sci. Pollut. Res. 2020, 27, 8535-8547. [CrossRef]

16. Cai, W.; Dou, L.; Zhang, M.; Cao, W.; Shi, J.; Feng, L. A fuzzy comprehensive evaluation methodology for rock burst forecasting using microseismic monitoring. Tunn. Undergr. Space Technol. 2018, 80, 232-245. [CrossRef]

17. Pramanik, R.; Baidya, D.K.; Dhang, N. Implementation of fuzzy reliability analysis for elastic settlement of strip footing on sand considering spatial variability. Int. J. Geomech. 2019, 19, 04019126. [CrossRef]

18. Zhao, S.; Zhang, D.; Huang, H. Deep learning-based image instance segmentation for moisture marks of shield tunnel lining. Tunn. Undergr. Space Technol. 2020, 95, 103156. [CrossRef]

19. Mottahedi, A.; Ataei, M. Fuzzy fault tree analysis for coal burst occurrence probability in underground coal mining. Tunn. Undergr. Space Technol. 2019, 83, 165-174. [CrossRef]

20. Duzgun, H.S.B.; Einstein, H.H. Assessment and management of roof fall risks in underground coal mines. Saf. Sci. 2004, 42, 23-41. [CrossRef]

21. Jiang, W.; Qu, F.; Zhang, L. Quantitative Identification and Analysis on Hazard Sources of Roof Fall Accident in Coal Mine. Procedia Eng. 2012, 45, 83-88. [CrossRef]

22. Ala, C.K.; Tripathy, D.P. Qualitative Assessment of Strata Control in an Indian Underground Coal Mine. J. Inst. Eng. 2016, 97, 99-104. [CrossRef]

23. Tripathy, D.P.; Ala, C.K. Risk Assessment in Underground Coalmines Using Fuzzy Logic in the Presence of Uncertainty. J. Inst. Eng. 2018, 99, 157-163. [CrossRef] 
24. Tripathy, D.P.; Ala, C.K. Identification of safety hazards in Indian underground coal mines. J. Sustain. Min. 2018, 17, 175-183. [CrossRef]

25. Xie, J.; Xu, J.; Zhu, W. Gray algebraic curve model-based roof separation prediction method for the warning of roof fall accidents. Arab. J. Geosci. 2016, 9, 514. [CrossRef]

26. Martin, B.; Bruce, H.; Rudrajit, M. Coal mine roof rating (CMRR), rock mass rating (RMR) and strata control: Carborough Downs Mine, Bowen Basin, Australia. Int. J. Min. Sci. Technol. 2020, 30, 225-234. [CrossRef]

27. Bai, C.; Xue, Y.; Qiu, D.; Yang, W.; Su, M.; Ma, X. Real-Time Updated Risk Assessment Model for the Large Deformation of the Soft Rock Tunnel. Int. J. Geomech. 2021, 21, 04020234. [CrossRef]

28. Tong, R.; Zhang, Y.; Yang, Y.; Jia, Q.; Ma, X.; Shao, G. Evaluating Targeted Intervention on Coal Miners' Unsafe Behavior. Int. J. Environ. Res. Public Health 2019, 16, 422. [CrossRef]

29. Yu, K.; Cao, Q.; Xie, C.; Qu, N.; Zhou, L. Analysis of intervention strategies for coal miners' unsafe behaviors based on analytic network process and system dynamics. Saf. Sci. 2019, 118, 145-157. [CrossRef]

30. Sajjad, A.; Gholamreza, S.; Hossein, J. Risk analysis of roof fall and prediction of damaged regions at retreat longwall coal mining face. Rudarsko-Geološko-Naftni Zbornik 2020, 35, 85-95. [CrossRef]

31. Li, D.; Fan, D.; Dong, C. Ecological Environment Evaluation of Coal Mining Area Based on Cloud Model. Adv. Mater. Res. 2012, 1566, 1372-1376. [CrossRef]

32. Liang, X.; Liang, W.; Zhang, L.; Guo, X. Risk assessment for long-distance gas pipelines in coal mine gobs based on structure entropy weight method and multi-step backward cloud transformation algorithm based on sampling with replacement. J. Clean. Prod. 2019, 227, 218-228. [CrossRef]

33. Yan, F.; Li, Z.; Dong, L.; Huang, R.; Cao, R. Cloud model-clustering analysis based evaluation for ventilation system of underground metal mine in alpine region. J. Cent. South Univ. 2021, 28, 796-815. [CrossRef]

34. Liu, Z.; Shao, J.; Xu, W.; Xu, F. Comprehensive Stability Evaluation of Rock Slope Using the Cloud Model-Based Approach. Rock Mech. Rock Eng. 2014, 47, 2239-2252. [CrossRef]

35. Gu, X.; Wu, S.; Ji, X.; Zhu, Y.; Oliveto, G. The Risk Assessment of Debris Flow Hazards in Banshanmen Gully Based on the Entropy Weight-Normal Cloud Method. Adv. Civ. Eng. 2021, 2021, 8841310. [CrossRef]

36. Elkin, K.E.; Vasenin, I.M. Mathematical modeling of sedimentation of a rarefied cloud of particles. Russ. Phys. J. 1999, 42, 333-336. [CrossRef]

37. Li, T.; Yang, X. Reliability analysis of tunnel face in broken soft rocks using improved response surface method. Int. J. Geomech. 2018, 18, 04018021. [CrossRef]

38. Tan, F.; Wang, J.; Jiao, Y.; Ma, B.; He, L. Suitability evaluation of underground space based on finite interval cloud model and genetic algorithm combination weighting. Tunn. Undergr. Space Technol. 2021, 108, 103743. [CrossRef]

39. Wang, J.; Liu, J.; Wei, Q.; Wang, P. Risk Assessment Based on Combined Weighting-Cloud Model of Tunnel Construction. Teh. Vjesn. 2021, 28, 203-210. [CrossRef]

40. Xu, Q.; Xu, K.; Li, L.; Yao, X. Safety assessment of petrochemical enterprise using the cloud model, PHA-LOPA and the bow-tie model. R. Soc. Open Sci. 2018, 5, 180212. [CrossRef]

41. Ju, F.; Huang, P.; Guo, S.; Xiao, M.; Lan, L. A roof model and its application in solid backfilling mining. Int. J. Min. Sci. Technol. 2017, 27, 139-143. [CrossRef]

42. Wu, Z.; Qiu, S.; Li, Y. Numerical Simulation of Inclined Multi-Seam Mining Subsidence of Considered the Impact by Faults. Adv. Mater. Res. 2011, 1270, 2135-2140. [CrossRef]

43. Tong, R.; Zhai, C.; Jia, Q.; Wu, C.; Liu, Y.; Xue, S. An Interactive Model among Potential Human Risk Factors: 331 Cases of Coal Mine Roof Accidents in China. Int. J. Environ. Res. Public Health 2018, 15, 1144. [CrossRef] [PubMed]

44. Gao, P. Research on Unsafe Acts and Control Method of Coal Mine Roof Accidents in China. Ph.D. Thesis, China University of Mining \& Technology, Beijing, China, 26 June 2016.

45. Firdaus, A.; Dina, E.; Asep, K.; Raju, W.; Supratman, Z. Decision Support System in Detrmination of Project Tender Winner Using the Analytical Hierarchy Process (AHP) Method. J. Phys. Conf. Ser. 2021, 1779, 012006. [CrossRef]

46. Xie, H.; Ma, J.; Fu, X.; Tian, Y. Regional Credit Environment Evaluation Based on Analytic Hierarchy Process (AHP) Method and Fuzzy Comprehensive Evaluation (FCE). J. Phys. Conf. Ser. 2021, 1813, 012060. [CrossRef]

47. Zaelani, A.A.; Hidayatul, H.M.; Bisma, I.; Sri, W.; Heneng, P.S.; Perdana, W.A.; Ari, W. Analysis of Decision Support System with Analytical Hierarchy Process Method. J. Phys. Conf. Ser. 2021, 1783, 012017. [CrossRef]

48. Praveenkumar, S.; Sankarasubramanian, G.; Sindhu, S. Selecting optimized mix proportion of bagasse ash blended high performance concrete using analytical hierarchy process (AHP). Comput. Concr. 2019, 23, 459-470. [CrossRef]

49. Saaty, T. A scaling method for priorities in hierarchical structures. J. Math. Psychol. 1977, 15, 234-281. [CrossRef]

50. Ishizaka, A.; Labib, A. Analytic Hierarchy Process and Expert Choice: Benefits and limitations. OR Insight 2009, 22, 201-220. [CrossRef]

51. Li, D.; Liu, C.; Gan, W. A new cognitive model: Cloud model. Int. J. Intell. Syst. 2009, 24, 357-375. [CrossRef]

52. Wu, S.; Wang, M.; Zou, Y. Bidirectional cognitive computing method supported by cloud technology. Cogn. Syst. Res. 2018, 52, 615-621. [CrossRef] 